\title{
Evaluation of p53, Caspase-3, Bcl-2, and Ki-67 markers in oral squamous cell carcinoma and premalignant epithelium in a sample from Alava Province (Spain)
}

\author{
Antonio Bascones-Martínez ${ }^{1}$, Carlos Rodríguez-Gutierrez ${ }^{2}$, Enrique Rodríguez-Gómez ${ }^{3}$, José-Antonio Gil- \\ Montoya ${ }^{4}$, Rafael Gómez-Font ${ }^{5}$, Miguel-Ángel González-Moles ${ }^{6}$
}

\begin{abstract}
${ }^{1} \mathrm{MD}$, DDS, PhD, Chairman of Oral Medicine and Periodontology, Department of Medicine and Bucofacial Surgery, Dental School, Complutense University of Madrid, Plaza Ramón y Cajal 3, Ciudad Universitaria, 28040-Madrid, Spain

${ }^{2}$ DDS, PhD, Department of Medicine and Bucofacial Surgery, Dental School, Complutense University of Madrid, Plaza Ramón y Cajal 3, Ciudad Universitaria, 28040-Madrid, Spain

${ }^{3} \mathrm{MD}, \mathrm{PhD}$, Chief Service, Hospital de Txagorritxu (Osakidetza) Alava Street, no 45, 01006 Vitoria, Álava, Spain

${ }^{4}$ MD, DDS, PhD, Full Professor, Department of Oral Medicine, School of Dentistry, Granada University, Campus de la Cartuja, Avda. de Madrid s/n, 18071-Granada, Spain

${ }^{5} \mathrm{MD}$, DDS, PhD, Associate Professor, Department of Medicine and Bucofacial Surgery, Dental School, Complutense University of Madrid, Plaza Ramón y Cajal 3, Ciudad Universitaria, 28040-Madrid, Spain

${ }^{6} \mathrm{MD}$, DDS, PhD, Chairman, Department of Oral Medicine, School of Dentistry, Granada University, Campus de la Cartuja, Avda. de Madrid s/n, 18071-Granada, Spain
\end{abstract}

Correspondence:

Department of Medicine and Bucofacial Surgery

Dental School, Complutense University of Madrid

Plaza Ramón y Cajal 3, Ciudad Universitaria

28040-Madrid, Spain

antbasco@odon.ucm.es

Bascones-Martínez A, Rodríguez-Gutierrez C, Rodríguez-Gómez E, Gil-Montoya JA, Gómez-Font R, González-Moles MA. Evaluation of p53, Caspase-3, Bcl-2, and Ki-67 markers in oral squamous cell carcinoma and premalignant epithelium in a sample from Alava Province (Spain). Med Oral Patol Oral Cir Bucal. 2013 Nov 1;18 (6):e846-50.

Received: 08/11/2012 Accepted: $23 / 03 / 2013$ http://www.medicinaoral.com/medoralfree01/v18i6/medoralv18i6p846.pdf

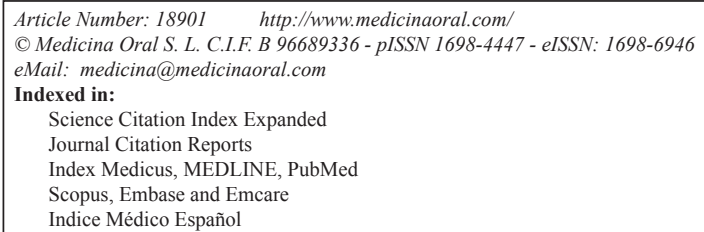

\begin{abstract}
Objectives: The objective of this study was to determine whether alterations in the expression of p53, caspase-3 Bcl-2, and ki-67 appear early in premalignant oral epithelium and show clonal behavior.

Study Design: Samples from 41 tumors with their adjacent non-tumor epithelia were immunohistochemically analyzed using monoclonal antibodies that recognize $\mathrm{p} 53$, caspase-3, Bcl-2, and Ki-67

Results: A statistically significant association was found between the expression in tumor and adjacent epithelium of p53, caspase-3, and Bcl-2 but not of k-67. A significant association was observed between the expression of ki-67 and p53 in both localizations. In non-tumor (premalignant) epithelium samples, there was a significant inverse relationship between the expressions of p53 and caspase- 3 and a significant direct relationship between the expressions of $\mathrm{p} 53$ and $\mathrm{Bcl}-2$.

Conclusions: Alterations in these proteins appear to operate in combination with premalignant epithelia to create hyperproliferative cell states that favor the acquisition of summative oncogenic errors that confer invasive capacity.
\end{abstract}

Key words: Cell cycle, apoptosis, p53, caspase-3, Bcl-2, Ki-67. 


\section{Introduction}

Cancerous cells are able to elude growth-inhibiting signals and develop mechanisms to evade apoptosis (1). They enter a pathological proliferative process that does not respond to exogenous growth signals, losing the main cell proliferation control mechanisms linked to the expression of tumor suppressor genes, whose main function is to halt the cell cycle for DNA repair, and developing anti-apoptotic molecular mechanisms (2). These molecular alterations are essential for cancer development and for the persistence of an uncontrolled proliferative state, in which the probability of oncogenic errors related to cell division increases due to so-called genomic instability. It is currently accepted that the development of oral cavity cancer is attributable to summative oncogenic alterations that appear very early and result in a progression from epithelial dysplasia through in situ carcinoma to invasive disease $(3,4)$. In this multistep process, precancerous epithelium may undergo malignant transformation through the alteration of chromosomal loci that host highly important tumor suppressor genes, such as $17 \mathrm{p} \mathrm{(5-7).} \mathrm{Furthermore,}$ molecular changes contributing to tumor development may be clonally transmitted by cells to their descendants, generating cell hierarchies predisposed to acquire new disorders that would eventually be responsible for persistent tumor growth.

Increasing knowledge of the molecular mechanisms involved in cancer development has enabled the development of molecular treatment strategies to reestablish the normal function of tumor suppressor genes in the tumor or to interrupt the intracellular pathways that transcribe aberrant growth signals, among other goals (1). Given that some disorders are established early, the application of these treatment strategies in premalignant cancer stages would help to prevent progression to invasion. This approach requires precise knowledge of early molecular events in the development of oral cancer (8).

Non-tumor epithelium adjacent to oral cancer represents a good example of a premalignant field in which antitumor control mechanisms have failed $(9,10)$. In the present study, tumor and adjacent non-tumor epithelium (ANTE) samples were immunohistochemically analyzed, evaluating the expression of the following markers: ki-67, to determine the global fraction of proliferative cells as indirect evidence of self-sufficient tumor cell growth; $\mathrm{p} 53$, the main tumor suppressor protein; caspase 3 , apoptotic marker; and Bcl-2, anti-apoptotic marker. The main objective of this study was to determine whether these proteins are altered early in premalignant fields and whether they behave clonally in cancer development.

\section{Material and Methods}

The study included 41 patients with Oral Squamous Cell Carcinoma (OSCC) under treatment in the Hos- pital of Txagorritxu (Osakidetza-Vitoria-Spain). After approval of the study by the hospital ethics committee, the hospital records of patients were reviewed and data were gathered on age, sex, reason for the first hospital visit, and the clinicopathological characteristics of the lesions, including their localization, size, stage, and degree of differentiation. Clinicopathological variables were considered missing when not found in the clinical records. Formalin-fixed and paraffin-embedded tumor tissue was available for all patients. The presence of ANTE with the tumors was recorded.

All biopsies were incisional and performed before the treatment, which was tumor resection in all cases. Only four patients ( $15 \%$ of the sample) were treated with radiotherapy, and no patient received chemotherapy. According to the TNM staging system, 20 patients (50\%) were T1N0M0, 17 patients (43\%) T2N0M0, and 4 patients (7\%) T3N0M0.

-Immunohistochemistry: For the immunohistochemical staining, 4- $\mu \mathrm{m}$ sections were cut from paraffin blocks. Peroxidase-antiperoxidase and avidin-biotin techniques were applied. The study was performed automatically using Autostainer Link equipment (Dako, Carpintería, CA, USA) and EmVision ${ }^{\mathrm{TM}}$ FLEX reagents (K8002; Dako, Carpintería, CA, USA). Primary antibodies were DO-7, Mib-1, anti-Bcl-2 (Dako, Carpintería, CA, USA) and anti-caspase-3 (Pharmagen, San Diego, CA). Manufacturers' instructions were rigorously followed. For the negative control, the primary antibody was replaced with phosphate buffer saline. For the positive control, tissue was used from an OSCC sample known to intensively express each protein. The result was considered positive when a brown color appeared in the cell nucleus (p53 and ki-67) or cytoplasm (caspase-3 and Bcl.2). Expression in premalignant and malignant epithelium was assessed in four randomized high-power fields (40×). Total cell number and number of positive cells were counted in each field, obtaining a mean percentage expression in each case. The count was made from the image on the computer screen.

Samples were assigned to one of the following categories, according to the mean percentage expression of positive cells found in each case: $0 \%$ positive cells $(-), 1-25 \%$ positive cells $(+), 26-50 \%$ positive cells $(++), 51-75 \%$ positive cells $(+++)$, or $>75 \%$ positive cells $(++++)$. This categorization was applied for all antibodies. In order to simplify the immunohistochemistry study, the results were grouped in two categories (0-25\% and 26-100\%).

Histological and immunohistochemical analyses were always performed by the same experienced examiner (MAGM), who was blind to the clinical stage, treatment, and course of the disease. Furthermore, both intra-(MAGM vs MAGM, 1 week apart) and inter-examiner (MAGM vs JGM, another experienced examiner) concordances were tested by repeating the marker observations in 13 samples. 
Quadratic weighted kappa values for intra- and inter-examiner concordance ranged from 0.62 to 0.95 , considered adequate according to the Landis \& Koch scale (11).

-Statistical analysis

SPSS 1.9 for Windows (IBM, Chicago IL) was used for the data analyses. A descriptive statistical analysis was performed (FREQUENCIES procedure), expressing qualitative data as frequencies and rates. Contingency tables were constructed (CROSSTABS procedure) to determine relationships among qualitative variables. The chi-square test and Pearson chi-square test were used to analyze independent qualitative variables.

\section{Results}

Table 1 shows the results of comparing expressions of p53, caspase 3, Bcl-2 and Ki 67 between tumor tissue and the accompanying ANTE. For all markers, with the exception of ki-67, a higher expression in ANTE was accompanied by a higher expression in tumor tissue. Table 2 compares the expression of p53 with the expressions of caspase-3, Bcl-2, and $\mathrm{Ki}-67$ in the tumor. A higher expression of ki-67 was accompanied by a higher expression of p53. Table 3 compares the expression of p53 with those of caspase-3, Bcl-2, and Ki-67 in the ANTE (Fig. 1).

\section{Discussion}

This study analyzed the expression of cell cycle regulators and proliferative markers in oral cancer. Limitations of this type of immunohistochemical study relate to the diverse antibodies used by different authors, the lack of agreement among researchers on cutoff points for considering a case positive, and difficulties in the evaluation. Nevertheless, immunohistochemical analysis yields considerable data on the topographical expression of markers and the relationships of positive cells with the surrounding cells. Our findings indicate that alterations in the expression and function of the main cell cycle-regulating proteins operate in combination with the multistep process of oral carcinogenesis to create a state of cell hyperproliferation (12), thereby favoring the occurrence of summative oncogenic events that enhance the proliferative and invasive activity of tumor cell clones. In this study, p53 expressions in OSCCs and in their associated ANTE were significantly associated (Table 1), demonstrating that p53 alterations are clonal and early oncogenic events in the multistep carcinogenesis of the oral mucosa. Alterations of p53 constitute an essential component of the oncogenic alterations that create genomic instability and decisively contribute to the transformation process rather than being secondary to the genomic instability of cell clones in the malignancy pathway $(13,14)$. Although immunohistochemistry has been reported to be an imprecise method to assess the mutational status of the p53 gene, due to discrepancies between protein expression and sequencing results, it is acknowledged that the immunohistochemical overexpression of p53 in premalignant epithelium indicates an incorrect functioning of the p53-related control system (5).

This interpretation is supported by our comparison between the expression of p53 and that of the other markers (Table 1). Thus, we observed a significant associa-

Table 1. Comparison of expressions of p53, Caspase 3, and Bcl-2and Ki- 67 between tumor epithelium and adjacent non-tumor epithelium (ANTE).

\begin{tabular}{|c|c|c|c|c|}
\hline \multicolumn{5}{|c|}{ p53 in ANTE } \\
\hline & $\begin{array}{c}\text { No ANTE } \\
\text { n(\%) }\end{array}$ & $\begin{array}{c}\text { Negative } \\
\text { n(\%) }\end{array}$ & $\begin{array}{c}\text { Positive } \\
\text { n(\%) }\end{array}$ & $\mathbf{p}$ \\
\hline $\begin{array}{l}\text { p53 in tumor } \\
0-25 \% \\
26-100 \%\end{array}$ & $\begin{array}{l}2(22.2) \\
7(77.7)\end{array}$ & $\begin{array}{c}14(63.6) \\
8(36.3)\end{array}$ & $\begin{array}{l}1(11.1) \\
8(88.8)\end{array}$ & $* *$ \\
\hline \multicolumn{5}{|c|}{ Caspase 3 in ANTE } \\
\hline $\begin{array}{l}\text { Caspase } 3 \text { in tumor } \\
0-25 \% \\
26-100 \%\end{array}$ & $\begin{array}{l}7(77.7) \\
2(22.2)\end{array}$ & $\begin{array}{c}15(88.2) \\
2(11.7)\end{array}$ & $\begin{array}{c}0 \\
2(100.0)\end{array}$ & $* *$ \\
\hline \multicolumn{5}{|c|}{ Bcl-2 in ANTE } \\
\hline $\begin{array}{l}\text { Bcl-2 in tumor } \\
0-25 \% \\
26-100 \%\end{array}$ & $\begin{array}{l}5(55.5) \\
4(44.4)\end{array}$ & $\begin{array}{c}26(92.8) \\
2(7.14)\end{array}$ & $\begin{array}{c}0 \\
4(100.0)\end{array}$ & $* *$ \\
\hline \multicolumn{5}{|c|}{ Ki 67 in ANTE } \\
\hline $\begin{array}{l}\text { Ki } \mathbf{6 7} \text { in tumor } \\
0-25 \% \\
26-100 \%\end{array}$ & $\begin{array}{l}2(22.2) \\
7(77.7)\end{array}$ & $\begin{array}{l}3(75.0) \\
1(25.0)\end{array}$ & $\begin{array}{l}6(40.0) \\
9(60.0)\end{array}$ & NS \\
\hline
\end{tabular}


Table 2. Association between expression of $\mathrm{p} 53$ and expressions of Caspase 3, Bcl-2, and Ki 67 in tumor samples.

\begin{tabular}{|l|c|c|c|}
\hline \multicolumn{4}{|c|}{ p53 in tumor } \\
\hline & $\mathbf{0 - 2 5 \%}$ & $\mathbf{2 6 - 1 0 0 \%}$ & $\mathbf{p}$ \\
\hline $\begin{array}{l}\text { Caspase 3 in } \\
\text { tumor } \\
0-25 \% \\
26-100 \%\end{array}$ & $\begin{array}{c}11(84.6) \\
2(15.3)\end{array}$ & $\begin{array}{c}10(66.6) \\
5(83.3)\end{array}$ & NS \\
\hline $\begin{array}{l}\text { Bcl2 in tumor } \\
0-25 \%\end{array}$ & $11(84.6)$ & $\begin{array}{c}10(62.5) \\
6(37.5)\end{array}$ & NS \\
$26-100 \%$ & $2(15.3)$ & & \\
\hline $\begin{array}{l}\text { Ki 67 in tumor } \\
0-25 \%\end{array}$ & $9(75.0)$ & $2(12.5)$ & $* *$ \\
$26-100 \%$ & $3(25.0)$ & $14(87.5)$ & \\
\hline
\end{tabular}

$* * \mathrm{p}<0.05$;

NS: not significant

Table 3. Association between expression of p53 and expressions of Caspase 3, Bcl-2, and Ki 67 in ANTE samples.

\begin{tabular}{|l|c|c|c|}
\hline \multicolumn{3}{|c|}{ p53 in ANTE } \\
\hline & $\begin{array}{c}\text { Negative } \\
\text { n(\%) }\end{array}$ & $\begin{array}{c}\text { Positive } \\
\text { n(\%) }\end{array}$ & p \\
\hline $\begin{array}{l}\text { Caspase 3 in ANTE } \\
\text { Negative } \\
\text { Positive }\end{array}$ & $\begin{array}{c}11(78.5) \\
2(14.2)\end{array}$ & $\begin{array}{c}5(100.0) \\
0\end{array}$ & $*$ \\
\hline $\begin{array}{l}\text { Bcl-2 in ANTE } \\
\text { Negative }\end{array}$ & $19(70.3)$ & $3(75.0)$ & $*$ \\
Positive & $8(29.6)$ & $1(25.0)$ & \\
\hline Ki 67 in ANTE & $5(100.0)$ & $9(64.2)$ & $*$ \\
Negative & 0 & $4(28.5)$ & \\
Positive & & & \\
\hline
\end{tabular}

$* \mathrm{p}<0.05$

tion between p53 and ki-67 in both tumor and ANTE, which may indicate that the overexpression of p53 corresponds to the loss of its cell-cycle repression functions (Tables 2,3). Moreover, our finding of an inverse association between the expression of $\mathrm{p} 53$ and that of caspase- 3 suggests that p53 is unable to arrest the cell cycle and also loses its apoptosis-inducing function in these epithelia (Tables 2,3). According to our results, the lack of apoptotic response in the ANTE is not only attributable to the loss of p53 function but also to a direct anti-apoptotic mechanism linked to the overexpression of Bcl-2 (15). The two oncogenic mechanisms (loss of p53 function and Bcl-2 overexpression) appear to operate in combination to suppress the apoptotic response in premalignant epithelium (16). Evidently, apoptosis suppression does not globally affect all of the cells of premalignant epithelia.

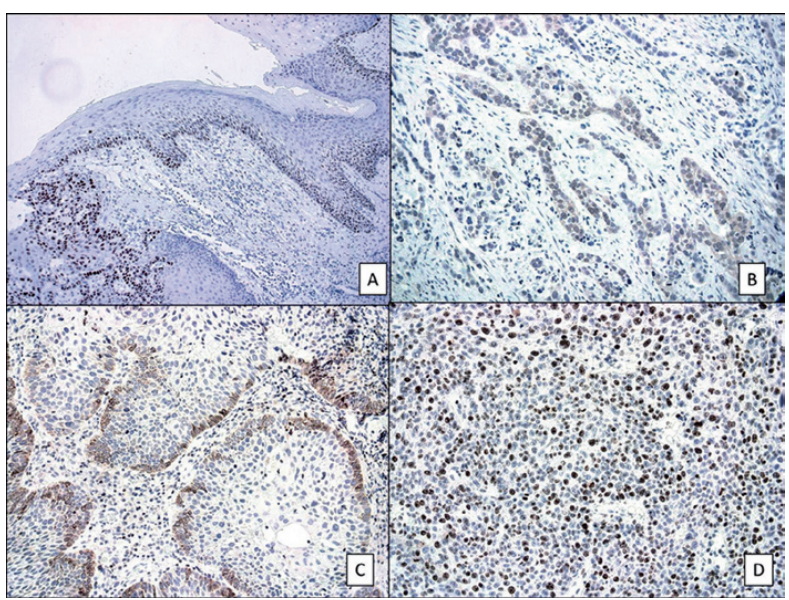

Fig. 1. A) P53 nuclear expression in premalignant and malignant oral epithelia (x100; immunohistochemical technique). B) Cytoplasmatic expression of caspase-3 in oral carcinoma (x100; immunohistochemical technique). C) Cytoplasmatic expression of $\mathrm{Bcl}-2$ at the invasion front of the oral carcinoma (x100; immunohistochemical technique). D) High expression of ki-67 in an oral carcinoma (x100; immunohistochemical technique).

We observed caspase-3 expression in some areas of ANTE, and there was a significant association between the expression of caspase-3 in ANTE and tumor (Table 3). In our opinion, this result indicates the presence of heterogeneous cell populations in premalignant fields and in the tumors that arise from them. Proliferation studies have shown that the persistent growth of a tumor or premalignant epithelium depends on a hierarchy of cells that have obtained a growth advantage, regardless of whether other cells in the same tissue develop apoptosis $(9,10)$. Cells within the tumor that are capable of developing apoptosis would not contribute to persistent tumor growth.

Finally, the lack of association between the expression of ki-67 in ANTE and in the associated tumor (Tables 2,3) indicates that the proliferative state in premalignant and malignant tissues varies according to the time course of the process and reflects the occurrence of late oncogenic events in the malignant cell population. These events would derive from genomic instability secondary to p53 changes, which would endow specific cell clones with proliferative and invasive advantages (17). These alterations would result from a loss of p53 function after gene mutation or from its inactivation by other causes and also from the effects of the demonstrated oncogenic functions of mutated p53 protein (2).

\section{Conclusions}

Our results suggest that $\mathrm{p} 53$ alterations are decisive oncogenic events in multistep oral carcinogenesis, alongside other oncogenic molecular processes that prevent the apoptotic response and lead to malignant transformation. Immunohistochemistry is a simple procedure that can be routinely applied and may help to identify 
patients requiring special follow-up and therapeutic measures. However, a wider study is required to verify these conclusions.

\section{References}

1. Hanahan D, Weinberg RA. The hallmarks of cancer. Cell. 2000;100:57-70.

2. Choi S, Myers JN: Molecular pathogenesis of oral squamous cell carcinoma: implications for therapy. J Dent Res. 2008;87:14-32.

3. Califano J, van der Riet P, Westra W, Nawroz H, Clayman G, Piantadosi S, et al: Genetic progression model for head and neck cancer: implications for field cancerization. Cancer Res.1996;56:2488-92.

4. Toner M, O'Regan EM: Head and neck squamous cell carcinoma in the young: a spectrum or a distinct group? Part 2. Head Neck Pathol. 2009;3:249-51.

5. Gasco M, Crook T: The p53 network in head and neck cancer. Oral Oncol. 2003;39:222-31.

6. Vogelstein B, Kinzler KW.The multistep nature of cancer. Trends Genet.1993;9:138-41.

7. Cabelguenne A, Blons H, de Waziers I, Carnot F, Houllier AM, Soussi T, et al. p53 alterations predict tumor response to neoadjuvant chemotherapy in head and neck squamous cell carcinoma: a prospective series. J Clin Oncol. 2000;18:1465-73.

8. Howard JD, Lu B, Chung CH. Therapeutic targets in head and neck squamous cell carcinoma: identification, evaluation, and clinical translation. Oral Oncol. 2012;48:10-7.

9. Gonzalez-Moles MA, Ruiz-Avila I, Gil-Montoya JA, Esteban F, Bravo M: Analysis of Ki-67 expression in oral squamous cell carcinoma: why Ki-67 is not a prognostic indicator. Oral Oncol. 2010;46:525-30.

10. González-Moles MA, Bravo M, Ruiz-Avila I, Acebal F, Gil-Montoya JA, Brener S, et al.: Ki-67 expression in non-tumor epithelium adjacent to oral cancer as risk marker for multiple oral tumors. Oral Dis. 2010;16:68-75.

11. Landis JR, Koch GG: The measurement of observer agreement for categorical data. Biometrics. 1977;33:159-74.

12. Liu SC, Klein-Szanto AJ: Markers of proliferation in normal and leukoplakia oral epithelia. Oral Oncol. 2000;36:145-51.

13. Levine AJ, Momand J, Finlay CA: The p53 tumor suppressor gene. Nature. 1991;351:453-6.

14. Baral R, Patnaik S, Das BR: Co-overexpression of p 53 and c-myc proteins linked with advanced stages of betel- and tobacco-related oral squamous cell carcinomas from eastern India. Eur J Oral Sci. 1998;106:907-13.

15. Miyashita T, Krajewski S, Krajewska M, Wang HG, Lin HK, Liebermann DA, et al. Tumor suppressor p53 is a regulator of bcl-2 and bax gene expression in vitro and in vivo. Oncogene. 1994;9:1799805

16. Wilson GD, Saunders MI, Dische S, Richman PI, Daley FM, Bentzen SM: Bcl-2 expression in head and neck cancer: an enigmatic prognostic marker. Int J Radiat Oncol Biol Phys. 2001;49:435-41.

17. Braakhuis BJ, Tabor MP, Kummer JA, Leemans CR, Brakenhoff RH: A genetic explanation of Slaughter's concept of field cancerization: evidence and clinical implications. Cancer Res. 2003;63:172730.

\section{Conflicts of interest}

The authors report no conflicts of interest.

Acknowledgments

The author ABM was supported by grant from Fundación Mutua Madrileña (AP 87102011). 